\title{
Total Phenolic and Caffeic Acid Contents in Roots of Solanum indicum L. from Different Agroclimatic Regions of Madhya Pradesh State of India
}

\author{
Hari Om Saxena*, Ganesh Pawar \\ NWFP Section, Silviculture, Forest Management and Agroforestry Division, Tropical Forest Research Institute, Jabalpur, Madhya \\ Pradesh, INDIA.
}

\begin{abstract}
Introduction: Solanum indicum L. is one of the species of Dashmularishta, a wellestablished ayurvedic medicine used in the treatment of fatigue, oral sores and gynecological disorders. The present investigation dealt with the estimation of total phenolic and caffeic acid contents in roots of $S$. indicum from different agroclimatic regions of Madhya Pradesh. Materials and Methods: The roots were collected from 8 places of 7 agroclimatic regions of Madhya Pradesh following purposive sampling. Phenolic content was determined with spectrophotometric method and caffeic acid content was estimated using HPTLC device. Results: The roots from Indore (Malwa plateau) and Balaghat (Chhattisgarh plains) contained maximum $(0.859 \%)$ and minimum $(0.595 \%)$ phenolic content respectively. Similarly, the highest content of caffeic acid was detected in the roots $(0.0198 \%)$ collected from Chhindwara and Betul (Satpura plateau) and lowest content $(0.0084 \%)$ in roots of Amarkantak (Northern Hill's Zone of Chhattisgarh). Conclusion: The present investigation revealed the highest phenolic content in root samples of Indore belonging to Malwa plateau and maximum content of caffeic acid in root samples of Chhindwara and Betul belonging to Satpura plateau agroclimatic regions. The populations of Chhindwara and Betul can be considered as superior chemotypes in terms of caffeic acid content and can be in-situ as well as ex-situ conserved for future.
\end{abstract}

Key words: Solanum indicum, Roots, Phenols, Caffeic acid, Agroclimatic regions, Superior chemotypes.

\section{INTRODUCTION}

Solanum indicum L. is commonly known as Birhata or Badi Kateri or Indian night shade and belongs to the family Solanaceae. It is an erect undershrub of 0.30 to $1.8 \mathrm{~m}$ in height and found throughout warmer parts of India, Asia and Africa upto an elevation of $1.5 \mathrm{~m} .{ }^{1}$ The national demand of S. indicum is 500-1000 MT per annum. ${ }^{2}$ Due to high demand and overexploitation, the herb has become rare in Madhya Pradesh. ${ }^{3,4}$ All plant parts viz. berries, leaves, roots, seeds and stem of this species have been utilized in traditional system of medicine and are useful in various diseases such as bronchitis, asthma, dry cough, rhi- nitis, dysuria, leucoderma, sexual disorders, insomnia, cardiac weakness and pruritis.-8 The plant has been documented in Chinese folk medicine as anti-inflammatory and wound-healing agents and as an analgesic for toothache, rhinitis and breast cancer. The species is among the ten medicinal plants whose roots are principally employed in preparation of Dashmularishta, a wellestablished ayurvedic drug used in the treatment of fatigue, oral sores and gynecological disorders. ${ }^{10}$ The basic ingredient of Dashmularishta is utilized in the manufacture of over hundred ayurvedic drugs. ${ }^{11}$ The pharmacological potential of a plant
Submission Date: 25-10-2018; Revision Date: 28-12-2018; Accepted Date: 20-03-2019.

DOI: 10.5530/ijper.53.2s.62 Correspondence: Dr. Hari Om Saxena, NWFP Section, Silviculture, Forest Management and Agroforestry Division, Tropical Forest Research Institute, Jabalpur Madhya Pradesh482021, INDIA.

Phone: +91-9131649342

E-mail: hariomsaxena81@ gmail.com

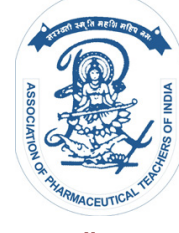

www.ijper.org 
lies in its active chemical ingredients, also called secondary metabolites and high content of active ingredients provides superior chemotypes. Madhya Pradesh state is endowed with rich and diverse flora and is divided into 11 agro-climatic regions. Active ingredients being the secondary metabolites are often influenced by the environmental and edaphic factors and vary from one region to another. ${ }^{12}$ Hence, the standardization of herb is the need of the hour. WHO and modern herbal pharmacopoeia lay a strong emphasis on the need for quality standardization of herbs with respect to their active ingredients. ${ }^{13-15}$ Phenolics are the most common and widely distributed plant phytoconstituents (Figure 1). ${ }^{16-}$ ${ }^{18}$ These possess broad spectrum of bioactivities such as antioxidant, anti-allergic, anti-carcinogenic or antimutagenic, anti-inflammatory, antibacterial, anti-fungal, anti-viral etc. ${ }^{19-25}$ Many research reports supported the phenolic compounds as an essential health promoting agents. ${ }^{26,27}$ The present investigation dealt with the estimation of total phenolic and caffeic acid contents in roots of S. indicum collected from different agroclimatic regions of Madhya Pradesh to find out the variations and superior chemotypes.

\section{MATERIALS AND METHODS}

\section{Collection and Processing of Plant Material}

Roots of S. indicum were collected from 8 places of 7 agroclimatic regions following purposive sampling as per availability in the state. These were washed thoroughly in running water to remove soil and other foreign particles. The roots were cut into small pieces and dried in shade and subsequently in a hot air oven at $40^{\circ} \mathrm{C}$ for $48 \mathrm{hr}$. Dried materials were powdered using grinder and stored in polythene bags for further phytochemical analysis. GPS readings of collection sites were recorded. The herbarium of plant specimen was deposited in Tropical Forest Research Institute, Jabalpur and identification no. 1761 was obtained.

\section{Quantification of Total Phenolic Content}

Total phenols were determined by Folin Ciocalteau method. ${ }^{28} 0.5$ gm of powdered sample in 10 times volume of $80 \%$ ethanol was grinded using a motor and pestle. The homogenate was then centrifuged at 10,000 rpm for $20 \mathrm{~min}$. The supernatant was then evaporated to dryness. The residue was dissolved in a known volume of distilled water. $0.2 \mathrm{ml}$ of this sample was then taken in test tube and volume made up to $3 \mathrm{ml}$ with distilled water. $0.5 \mathrm{ml}$ of Folin Ciocalteau reagent was then added. After 3 min, $2 \mathrm{ml}$ of $20 \% \mathrm{Na}_{2} \mathrm{CO}_{3}$ solution was added, mixed thoroughly, placed in boiling water for exactly 1 min, cooled and absorbance was taken at 650 $\mathrm{nm}$ against blank. The standard graph was prepared by using different concentrations of catechol. Percentage of phenol was calculated from the following formula:

Percentage of Phenol $=\frac{\text { Amount of standard }}{\text { O.D. of standard }} \times \frac{\text { 0.D. of sample }}{\text { Weight of sample }} \times \frac{\text { Total volume makeup }}{\text { Volume taken }} \times 100$

\section{Quantification of caffeic acid using HPTLC}

\section{Preparation of extracts}

$2.5 \mathrm{gm}$ dried and finely powdered root samples were taken in conical flasks containing $50 \mathrm{ml}$ of $2 \mathrm{~N}$ HCL and heated for 30 min over a boiling water bath, cooled and filtered. The filtrate was transferred to a separating funnel and extracted with $75 \mathrm{ml}$ (50:25) of diethyl ether. The combined diethyl ether layers were washed two times with distilled water, dried over anhydrous sodium sulphate and filtered. The filtrate was evaporated and concentrated extract was dissolved in $2 \mathrm{ml}$ of methanol for analysis.

\section{Preparation of standard solution}

Caffeic acid purchased from Sigma Aldrich India, was used as chemical standard. Standard solution of $0.1 \mathrm{mg} /$ $\mathrm{ml}$ concentration was prepared for calibration graph.

\section{Standardization of solvent system for HPTLC}

A number of solvent systems were tried, but the satisfactory resolution of caffeic acid in the extracts was obtained in the solvent combination of Cyclohexane: Ethyl acetate: Formic acid (6: 4:1).

\section{Sample application}

$10 \mu \mathrm{l}$ of each sample was spotted in triplicate in the form of bands of width $8 \mathrm{~mm}$ using a $100 \mu \mathrm{l}$ CAMAG syringe on $20 \times 10 \mathrm{~cm}$ aluminum packed TLC plate coated with $0.2 \mathrm{~mm}$ layer of silica gel 60F 254 (E. Merck Ltd., Darmstadt, Germany) with the help of LinomatV applicator attached to CAMAG HPTLC system, which was programmed through winCATS software. Different volumes of standard solution such as 4, 6, 8, 10 and 12 $\mu \mathrm{l}$ (Corresponding to 40, 60, 80, 100 and 120 ng respectively of caffeic acid) were applied on HPTLC plate in five tracks.

\section{Development of chromatograms}

$20 \mathrm{ml}$ of mobile phase Cyclohexane: Ethyl acetate: Formic acid (6:4:1) was used per chromatography run. The linear ascending was carried out in a twin glass chamber (20 cm x $10 \mathrm{~cm}$ dimension) saturated with mobile phase.

\section{Detection of spots}

The developed HPTLC plate was dried by hot air to evaporate solvents from the plate and kept in photo - 
documentation chamber. Images of plates were captured under UV light at 254 and $366 \mathrm{~nm}$ respectively. Densitometric scanning was then performed with a CAMAG TLC Scanner 4 equipped with winCATS software at $\lambda_{\max }=330 \mathrm{~nm}$ using deuterium and tungsten light source. The slit dimensions were $6.00 \times 0.45 \mathrm{~mm}$. Respective peak areas were recorded and a calibration curve was prepared by plotting the peak areas vs. concentrations of caffeic acid standard applied. Amount of caffeic acid in plant extracts was calculated by using the calibration curve of standard.

\section{Statistical Analysis}

Data were statistically analyzed. Each experiment was carried out in triplicate and the results are expressed as Mean $\pm \mathrm{SD}(n=3)$. ANOVA was applied to check the results as significant and non - significant.

\section{RESULTS AND DISCUSSION}

The collection sites along with, agroclimatic regions and GPS locations are given in Table 1. Total phenolic and caffeic acid contents in roots of $S$. indicum collected from 8 sites of 7 agroclimatic regions are given in Table 2. Total phenolic contents in root samples varied from $0.859 \%$ (Indore, Malwa plateau) to $0.595 \%$ (Balaghat, Chhattisgarh plains) (Figure 2). Similarly, caffeic acid content in root samples differed from $0.0198 \%$ (Chhindwara and Betul, Satpura plateau) to 0.0084\% (Amarkantak, Northern Hill's Zone of Chhattisgarh) (Figure 3). Thus, the maximum phenolic content $(0.859 \%)$ was found in the root samples of Indore belonging to Malwa plateau agroclimatic region and maximum caffeic acid content $(0.0198 \%)$ was found in the root samples of Chhindwara and Betul belonging to Satpura plateau agroclimatic region. Significant variations in total phenol and caffeic acid contents were found among the root samples collected from various agroclimatic regions of Madhya Pradesh state of India.
Estimates of total phenolic and caffeic acid contents did not exhibit positive co-relation between themselves because total phenols represent a group of phenolic compounds and it may be concluded that root samples of different places may contain other phenolic compounds also along with caffeic acid. Besides, variations in secondary metabolite concentrations due to abiotic and stress factors viz. temperature, altitude, soil, rainfall, humidity, drought, light intensity, high salinity, supply of water, minerals, freezing temperatures and $\mathrm{CO}_{2}$ have been described by many researchers from time to time. ${ }^{29-35}$ The stress conditions triggered accumulation of secondary metabolites which help the plants to adapt according to environment and in overcoming stresses. ${ }^{36}$ In our earlier studies, we found out the variations in colchicine, lupeol and rhoifolin contents in Gloriosa superba, Hemidesmus indicus and Uraria picta respectively in Madhya Pradesh state. ${ }^{12,13,37}$ In other studies also, various authors

\begin{tabular}{|c|c|c|}
\hline Agro-climatic regions & $\begin{array}{l}\text { Places of } \\
\text { collection }\end{array}$ & GPS Location \\
\hline $\begin{array}{c}\text { Kymore Plateau and } \\
\text { Satpura Hills }\end{array}$ & Seoni & $\begin{array}{l}\text { N } 22^{\circ} 02^{\prime} 20.4^{\prime \prime} \\
\text { E } 79^{\circ} 25^{\prime} 48.1^{\prime \prime}\end{array}$ \\
\hline Chhattisgarh plains & Balaghat & $\begin{array}{l}\text { N } 21^{\circ} 57^{\prime} 21.6^{\prime \prime} \\
\text { E 80²5'21.9" }\end{array}$ \\
\hline $\begin{array}{c}\text { Central Narmada } \\
\text { Valley }\end{array}$ & Hoshangabad & $\begin{array}{l}\text { N } 22^{\circ} 26^{\prime} 28.0^{\prime \prime} \\
\text { E } 78^{\circ} 25^{\prime} 05.3^{\prime \prime}\end{array}$ \\
\hline Malwa Plateau & Indore & $\begin{array}{l}\text { N } 22^{\circ} 23^{\prime} 38.7^{\prime \prime} \\
\text { E } 75^{\circ} 39^{\prime} 28.3^{\prime \prime}\end{array}$ \\
\hline \multirow[t]{2}{*}{ Satpura Plateau } & Chhindwara & $\begin{array}{l}\text { N } 22^{\circ} 20^{\prime} 40.5^{\prime \prime} \\
\text { E } 78^{\circ} 39^{\prime} 57.4^{\prime \prime}\end{array}$ \\
\hline & Betul & 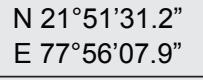 \\
\hline $\begin{array}{l}\text { Northern Hill Zone of } \\
\text { Chhattisgarh }\end{array}$ & Amarkantak & $\begin{array}{l}\text { N } 22^{\circ} 40^{\prime} 59.1^{\prime \prime} \\
\text { E } 81^{\circ} 45^{\prime} 07.7^{\prime \prime}\end{array}$ \\
\hline Vindhyan Plateau & Sehore & $\begin{array}{l}\text { N } 22^{\circ} 47^{\prime} 00.1^{\prime \prime} \\
\text { E } 77^{\circ} 37^{\prime} 13.2^{\prime \prime}\end{array}$ \\
\hline
\end{tabular}

\begin{tabular}{|c|c|c|c|}
\hline Agroclimatic regions & Places & 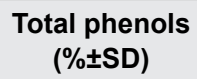 & 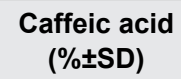 \\
\hline Kymore Plateau and Satpura Hills & Seoni & $0.802 \pm 0.02$ & $0.0196 \pm 0.003$ \\
\hline Chhattisgarh plains & Balaghat & $0.595 \pm 0.01$ & $0.0170 \pm 0.006$ \\
\hline Central Narmada Valley & Hoshangabad & $0.769 \pm 0.01$ & $0.0132 \pm 0.002$ \\
\hline Malwa Plateau & Indore & $0.859 \pm 0.01$ & $0.0164 \pm 0.001$ \\
\hline Satpura Plateau & Chhindwara and Betul & $0.738 \pm 0.09$ & $0.0198 \pm 0.002$ \\
\hline Northern Hill's Zone of Chhattisgarh & Amarkantak & $0.618 \pm 0.05$ & $0.0084 \pm 0.002$ \\
\hline Vindhyan Plateau & Sehore & $0.726 \pm 0.05$ & $0.0085 \pm 0.005$ \\
\hline
\end{tabular}




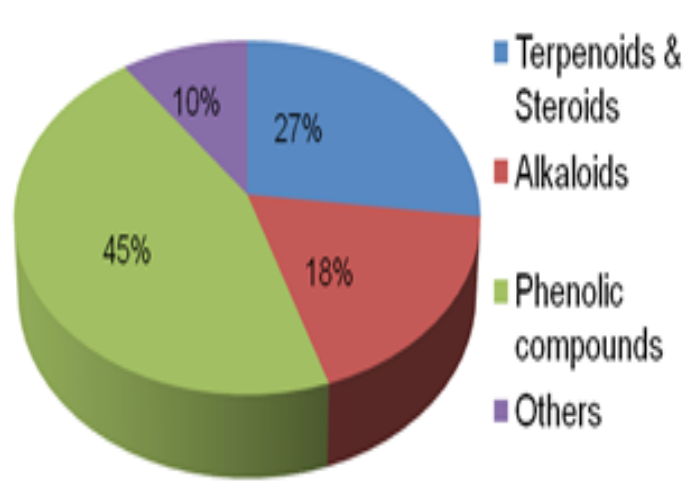

Figure 1: Perentage Distribution of Phytochemicals in Plants.

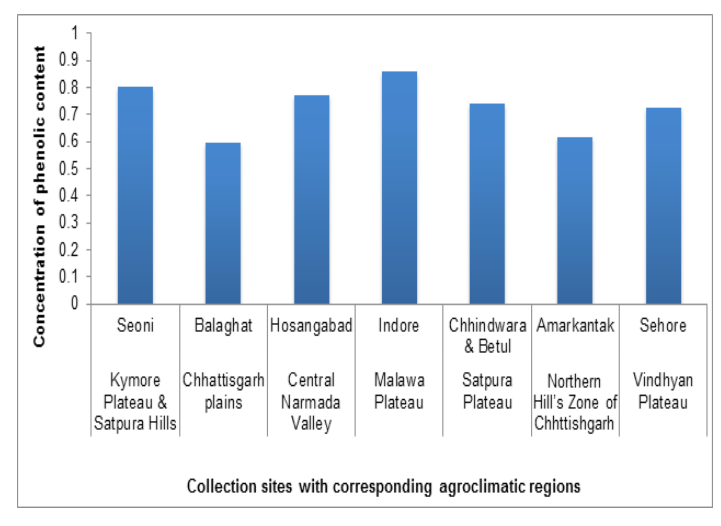

Figure 2: Total Phenolic Content in Roots of S. indicum.

reported the variations in respective active chemical ingredients of Terminalia arjuna, Embelia tsjeriam-cottam and Andrographis paniculata in Madhya Pradesh state and the results showed significant variations among the plant samples of different locations. ${ }^{38-40}$ Our present study is also in the same line of earlier studies. Caffeic acid and its phenethyl ester confer strong antioxidant, antimitogenic, anti-allergic, immuno-modulatory, antiinflammatory and anti-carcinogen activities both in-vitro and in-vivo. ${ }^{41-46}$ Hence, its presence in roots of S. indicum is validating the therapeutic potential and utilization of this plant in Ayurvedic system of medicine.

\section{CONCLUSION}

It emerged from the study that population of $S$. indicum in Chhindwara and Betul belonging to Satpura plateau agroclimatic region contained the maximum caffeic acid content, hence, these populations can be considered as superior chemotypes in terms of active chemical ingredient caffeic acid. The superior chemotypes of this commercially important but rare species can be in-situ as well as ex-situ conserved for their utilization as elite material in pharmaceutical industries, mass propagation and other research needs.

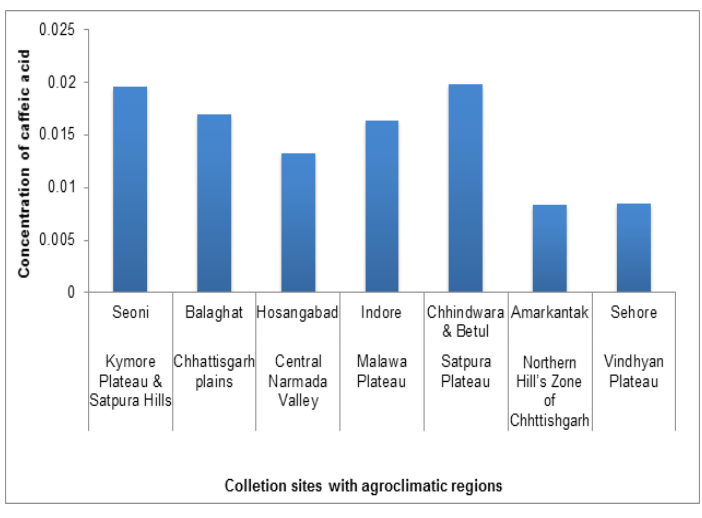

Figure 3: Caffeic Acid Content in Roots of S. indicum.

\section{ACKNOWLEDGEMENT}

Authors are thankful to the Director of the Institute to provide all necessary facilities to perform the research works. The financial support from ICFRE in the form of project (ID: 176) is heartily acknowledged.

\section{CONFLICT OF INTEREST}

The author declare no conflict of interest.

\section{ABBREVIATIONS}

L.: Linn; HPTLC: High Performance Thin Layer Chromatography; m: Meter; WHO: World Health Organization; ${ }^{\circ} \mathbf{C}$ : Degree centigrade; hr: Hour; GPS: Global Positioning System; gm: Gram; rpm: Round per minute; min: Minute; $\mathbf{m l}$ : Milliliter; $\mathrm{Na}_{2} \mathrm{CO}_{3}$ : Sodium carbonate; nm: Nano meter; N: Normality; HCL: Hydrochloric acid; mg: milligram; $\mu$ l: Microliter; cm: Centimeter; ng: Nanogram; UV: Ultraviolet; $\lambda_{\text {max }}$ : Wavelength maximum; vs.: Versus; mm: Millimeter; $\mathbf{C O}_{2}$ : Carbon dioxide; ICFRE: Indian Council of Forestry Research and Education.

\section{REFERENCES}

1. Hasan RU, Prabhat $P$, Shafaat K, Khan R. Phytochemical investigation and evaluation of antioxidant activity of fruit of Solanum indicum L. Int J Pharm Sci Res. 2013;5(3):237-42.

2. Nmpb.nic.in [homepage on the Internet]. New Delhi: National Medicinal Plants Board, Ministry of Ayush, Government of India. 2018. Available from: https://nmpb.nic.in/medicinal_list.

3. Kotak N. A comparative appraisal of Brihati (Solanum indicum L.) and its substitutes w.s.r. to its pharmacognostical physicochemical and pharmacological profile. I.P.G.T. and R.A., Gujrat Ayurved University (Jamnagar). 2008-09.

4. Joshi PR, Patel BR. Pratinidhi dravya and its adaptation in current scenario A bird's eye view. Research in Pharmacy. 2012;2(2):21-6.

5. Publications and Information Directorate, CSIR. The Wealth of India - Raw Materials, New Delhi (India).1986.

6. Bhakta T. Common Vegetables of the Tribals of Tripura. Agartala (India): Tripura Tribal Research Institute. 2004. 
7. Bhattacharya AS. Chiranjivi Banaushadhi. $2^{\text {nd }}$ reprint. Kolkata: Ananda Publishers. 1982;3.

8. Sharma V, Hem K, Seth A, Maurya SK. Solanum indicum Linn.: An ethnopharmacological, phytochemical and pharmacological review. Current Research Journal of Pharmaceutical and Allied Sciences. 2017;1(2):1-9.

9. Yin HL, Li JH, Li B, Chen L, Li J, Tian Y, et al. Two new coumarins from the seeds of Solanum indicum. J Asian Nat Prod Res. 2014;16(2):153-7.

10. Yadav AK, Yadav D, Shanker K, Verma RK, Saxena AK, Gupta MM. Flavone Glycoside Based Validated RP-LC Method for Quality Evaluation of Prishniparni (Uraria picta). Chromatographia. 2009;69(7-8):653-8.

11. Pathak JM, Krishnamurthy R, Chandorkar MS, Gulkari VD, Rajendra G. Identification of high yielding genotypes of Dashmool Shalparni (Desmodium gangeticum) drug plant and its cultivation under high density planting. Indian J Hortic. 2005;62(4):378-84.

12. Saxena HO, Mohan B, Kakkar A, Ganesh. Variation in colchicine content in tubers of Gloriosa superba L. from Madhya Pradesh for identification of elite chemotypes. International Journal of Chemical Studies. 2017;5(5):2278-82.

13. Saxena HO, Mohan B, Kakkar A. Assessment of Variation in Rhoifolin Content in Aerial Parts of Uraria picta Desv. from Different Locations of Madhya Pradesh. Journal of Pharmacy Research. 2016;10(5):185-90.

14. Sharma P, Kaushik S, Jain A, Sikarwar SM. Preliminary phytochemical screening and HPTLC fingerprinting of Nicotiana tabacum leaf. J Pharm Res. 2010;3(5):1144-5

15. Vasudevan H. DNA fingerprinting in the standardization of Herbs and Neutaceuticals. The Science Creative Quaterly. 2009;4

16. Herrmann K. Occurrence and content of hydroxycinnamic and hydroxybenzoic acid compounds in foods. Crit Rev Food Sci Nutr. 1989;28(4):315-47.

17. Kim D, Jeond S, Lee C. Antioxidant capacity of phenolic phytochemicals from various cultivars of plums. Food Chem. 2003;81(3):321-6.

18. Saxena M, Saxena J, Nema R, Singh D, Gupta A. Phytochemistry of Medicinal Plants. Journal of Pharmacognosy and Phytochemistry. 2003;1(6):168-82.

19. Saxena HO, Maolankar S, Madave R, Soni A, Gupta R. Quantification of phenolic acids in fruits of Solanum xanthocarpum from three agroclimatic regions of Madhya Pradesh using HPLC. Indian J Trop Biodiv. 2015;23(1):4652.

20. Han XZ, Shen T, Lou HX. Dietary polyphenols and their biological significance. Int J Mol Sci. 2007;8(9):950-88

21. Huang $\mathrm{WH}$, Hsu CW, Fang JT. Central diabetes insipidus following digestion Solanum indicum L. concentrated solution. Clin Toxicol (Phila). 2008;46(4):293-6

22. Silici S, Unlu M, Vardar-Unlu G. Antibacterial activity and phytochemical evidence for the plant origin of Turkish propolis from different regions. World J Microb Biot. 2007;23(12):1797-803.

23. Chaubal R, Mujumdar AM, Misar A, Deshpande NR. Isolation of phenolic compounds from Acacia nilotica with topical anti-inflammatory activity. Asian J Chem. 2005;17(3):1595-9.

24. Raghavendra MP, Kumar PR, Prakash V. Mechanism of inhibition of rice bran lipase by polyphenols- a case study with chlorogenic acid and caffeic acid. J Food Sci. 2007;72(8):412-9.

25. Larrosa M, Tomas-Barberan FA, Espin JC. The dietary hydrolysable tannin punicalagin releases ellagic acid that induces apoptosis in human colon adenocarcinoma Caco-2 cells by using the mitochondrial pathway. J Nutr Biochem. 2006;17(9):611-25

26. Hayashi T, Maruyama H, Kasai R, Hattori K, Takasuga S, Hazeki O, et al. Ellagitannins from Lagerstroemia speciosa as activators of glucose transport in fat cells. Planta Med. 2002;68(2):173-5.
27. Gayathri P, Gayathri DS, Srinivasan S, Saroja S. Screening and Quantitation of Phytochemicals and Nutritional Components of the Fruit and Bark of Helicteres isora. Hygeia J D Med. 2010;29(1):57-62.

28. McDonald S, Prenzler PD, Autolovich M, Robards K. Phenolic content and antioxidant activity of olive extracts. Food Chem. 2001;73(1):73-84.

29. Morison JIL, Lawlor DW. Interactions between increasing $\mathrm{CO}_{2}$ concentration and temperature on plant growth. Plant Cell Environ. 1999;22(6):659.

30. Sandeep IS, Sanghamitra N, Mohanty S. Differential effect of soil and environment on metabolic expression of turmeric (Curcuma longa cv. Roma). Indian J Exp Biol. 2015;53:406-11.

31. Garg SN, Bansal RP, Gupta MM, Kumar S. Variation in the rhizome essential oil and curcumin contents and oil quality in the land races of turmeric Curcuma longa of North Indian Plains. Flavour Fragr J. 1999;14(5):315.

32. Anandaraj M, Prasath D, Kanadiannan K, John ZT, Srinivasan V, Jha AK, et al. Genotype by environment interaction effects on yield and curcumin in turmeric (Curcuma longa L.). Ind Crops Prod. 2014;53:358.

33. Pothitirat W, Gritsanapan W. Variation of biotic components in Curcuma longa in Thailand. Curr Sci. 2006;01:1397.

34. Payyavula RS, Navarre DA, Kuhl JC, Pantoja A, Pollai SS. Differential effects of environment on potato phenylpropanoid and carotenoid expression. BMC Plant Biol. 2012;12(1):39-56.

35. Rao MR, Rao DVR. Genetic resources of turmeric, advances in horticulture. Plantation and spice crops. New Delhi; Malhotra Publishing House. 1994;131.

36. Ramakrishna A, Ravishankar GA. Influence of abiotic stress signals on secondary metabolites in plants. Plant Signal Behav. 2011;6(11):1720-31.

37. Saxena HO, Mohan B, Kakkar A, Pawar G. Chemotypic variation of lupeol in roots of Hemidesmus indicus (L.) R.Br. from different agroclimatic regions of Madhya Pradesh state of India. Current Traditional Medicine. 2017;3(1):2937.

38. Pandey AK, Kori DC. Variations in tannin and oxalic acid content in Terminalia arjuna (Arjuna) Bark. Phcog Mag. 2009;5(18):159-64.

39. Pandey AK, Ojha V. Estimation of embelin in Embelia tsjeriam-cottam fruits by HPLC to standardize harvesting time. Indian J Pharm Sci. 2011;73(2):2169

40. Mishra S, Tiwari SK, Kakkar A, Pandey AK. Chemoprofiling of Andrographis paniculata (kalmegh) for its andrographolide content in Madhya Pradesh, India. Int J Pharm Bio Sci. 2010;1(2):1-5.

41. Natarajan K, Singh S, Burke TR, Grunberger D, Aggarwal BB. Caffeic acid phenethyl ester is a potent and specific inhibitor of activation of nuclear transcription factor NF-KB. Proc Natl Acad Sci. 1996;93(17):9090-5.

42. Rajendra PN, Karthikeyan A, Karthikeyan S, Reddy BV. Inhibitory effect of caffeic acid on cancer cell proliferation by oxidative mechanism in human HT1080 fibrosarcoma cell line. Mol Cell Biochem. 2011;349(1-2):11-9.

43. Michaluart P, Masferrer JL, Carothers AM, Subbaramaiah K, Zweifel BS Koboldt $\mathrm{C}$, et al. Inhibitory effects of caffeic acid phenethyl ester on the activity and expression of cyclooxygenase-2 in human oral epithelial cells and in a rat model of inflammation. Cancer Res. 1999;59(10):2347-52.

44. Bhimani RS, Troll W, Grunberger D, Frenkel K. Inhibition of oxidative stress in HeLa cells by chemopreventive agents. Cancer Res. 1993;53(19):4528-33.

45. Jaiswal AK, Venugopal R, Mucha J, Carothers AM, Grunberger D. Caffeic acid phenethyl ester stimulates human antioxidant response elementmediated expression of the $\mathrm{NAD}(\mathrm{P}) \mathrm{H}$ : Quinone oxidoreductase (NQO1) gene. Cancer Res.1997;57(3):440-6.

46. Sudina GF, Mirzoeva NV, Pushkareva MA, Korshunova GA, Sumbatyan NV, Vafolomeev SD. Caffeic acid phenethyl ester as a lipoxygenase inhibitor with antioxidant properties. Feder Eur Biochem Soc. 1993;329(1-2):21-4 


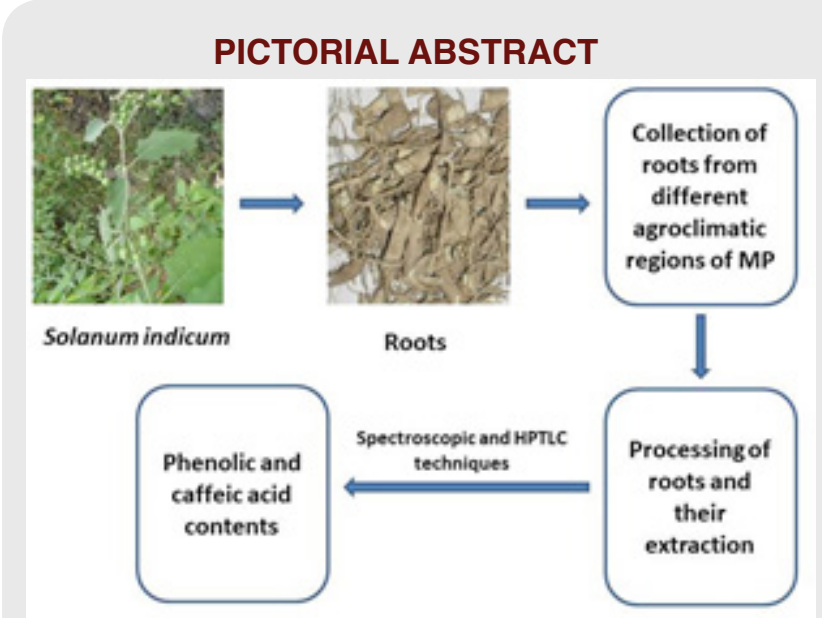

\section{SUMMARY}

- The roots of Solanum indicum were collected from different agroclimatic regions of Madhya Pradesh.

- Roots were processed and powdered. Root powders were extracted in suitable solvents.

- Phenolic and caffeic acid contents were determined using spectrophotometric and HPTLC methods respectively.

- Study showed the significant variations in phenolic and caffeic acid contents among the root samples of different agroclimatic regions.

\section{ABOUT AUTHORS}

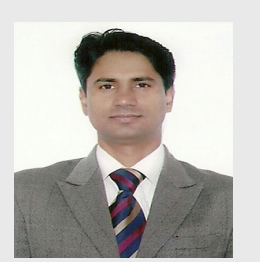

Dr. Hari Om Saxena received his M.Sc. from University of Lucknow, Lucknow (Uttar Pradesh) and PhD from Rani Durgavati Vishwavidyalaya, Jabalpur (Madhya Pradesh). His research interests include harvesting and post harvesting practices of Non Wood Forest Produce (NWFPs), their conservation, domestication and phytochemical analysis using sophisticated instruments.

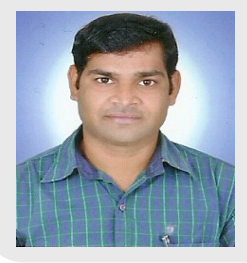

Shri Ganesh Pawar received his M.Sc. from Dr. Hari Singh Gaur University, Sagar (Madhya Pradesh). His research interests include conservation, domestication, harvesting and post harvesting practices of medicinal plants and their phytochemical analysis.

Cite this article: Saxena HO, Pawar G. Total Phenolic and Caffeic Acid Contents in Roots of Solanum indicum L. from Different Agroclimatic Regions of Madhya Pradesh State of India. Indian J of Pharmaceutical Education and Research. 2019;53(2S):s164-s169. 